\title{
A compact, self-contained zooplankton pump for use in shallow coastal habitats: design and performance compared to net samples*
}

\author{
P. Dixon \& A. I. Robertson \\ Australian Institute of Marine Science, P. M. B. 3, Townsville M. C., Queensland 4810, Australia
}

\begin{abstract}
A portable zooplankton pump system that can be operated by 1 person is described. Comparison of the taxonomic composition of zooplankton samples taken with the pump and a boat-towed net in a tropical, mangrovedominated estuary on 2 dates revealed significant correlations in the rank order of abundance of the major taxa captured by the 2 methods. Comparisons of densities of zooplankton taken by the 2 methods indicated that there was no significant difference in the mean abundances of the 3 taxa (copepods, nauplii and zoea) that made up more than $78 \%$ of the animals sampled on each date. However net samples yielded significantly greater numbers of chaetognaths, larvaceans and polychaete larvae, while pump samples held more gastropod and bivalve larvae. Several possible uses of the pump system are discussed.
\end{abstract}

Sampling of zooplankton with pumps in the open sea has several advantages over towed nets including reliable measurements of the filtered volume, depth control, and control of the filtering process with the possible use of several mesh sizes (Miller \& Judkins 1981). Consequently, large shipboard pumps have been designed and used for a variety of zooplankton studies (e.g. Aron 1958, Beers et al. 1967, Lenz 1972, Herman et al. 1984).

For many coastal systems such as reefs and kelp beds, it is often extremely difficult or impossible to sample zooplankton using boat-towed nets. Because of this, several methods, including man-powered nets (Hobson \& Chess 1976), light-traps (Sale et al. 1976, Tranter et al. 1981) and non-illuminated traps (e.g. Alldredge \& King 1977, Porter \& Porter 1977, Hobson \& Chess 1979) and pumps have been used to sample zooplankton in these habitats. Efforts to subsample water from the intakes of cooling systems of power

\footnotetext{
- Contribution No. 323 from the Australian Institute of Marine Science
}

(c) Inter-Research/Printed in F. R. Germany plants have led to the development of several pump samplers (e.g. Icanberry \& Richardson 1973, Yocum et al. 1978). Smaller, mare portable pumps have been used to sample lake and stream zooplankton (Waite \& O'Grady 1980, Williams 1985), but these devices require the use of a boat or a fixed platform for the power supply.

In this paper we describe a portable pumping system (EZY-ZOOP) that can be used by 1 person to take quantitative samples of zooplankton. The need for such a pump arose in the course of a study of the trophic interactions between fish and zooplankton in mangrove-dominated estuaries. We needed a sampler that would sample quantitatively the zooplankton present at high tide amongst the stems and prop roots of a mangrove habitat dominated by species of Rhizophora. Neither boats nor hand held nets could be used successfully in this environment. After giving a detailed description of the sampler we compare the catches taken by the pump and a standard plankton net.

Description of EZY-ZOOP sampler. The unit consists of 2 PVC pontoons supporting a base board on which the sampling equipment is mounted (Fig. 1). The water is pumped by a conventional $12 \mathrm{~V}$ bilge pump (Rule Co. Ltd, $1500 \mathrm{~g} \mathrm{~h}^{-1}$ ) attached to the underside of the base board. Power for the bilge pump is supplied by a $12 \mathrm{~V}$ motor vehicle battery mounted in a removable watertight box, which is sunk through the centre of the base board to form a stabilizing keel for the apparatus.

The pump is activated by a switch on top of the battery box, and water is pumped past a calibrated flow meter (General Oceanics Inc.) mounted on top of the receiving tank (Fig. 1). The flow meter is necessary since it is possible that pump output can vary with 


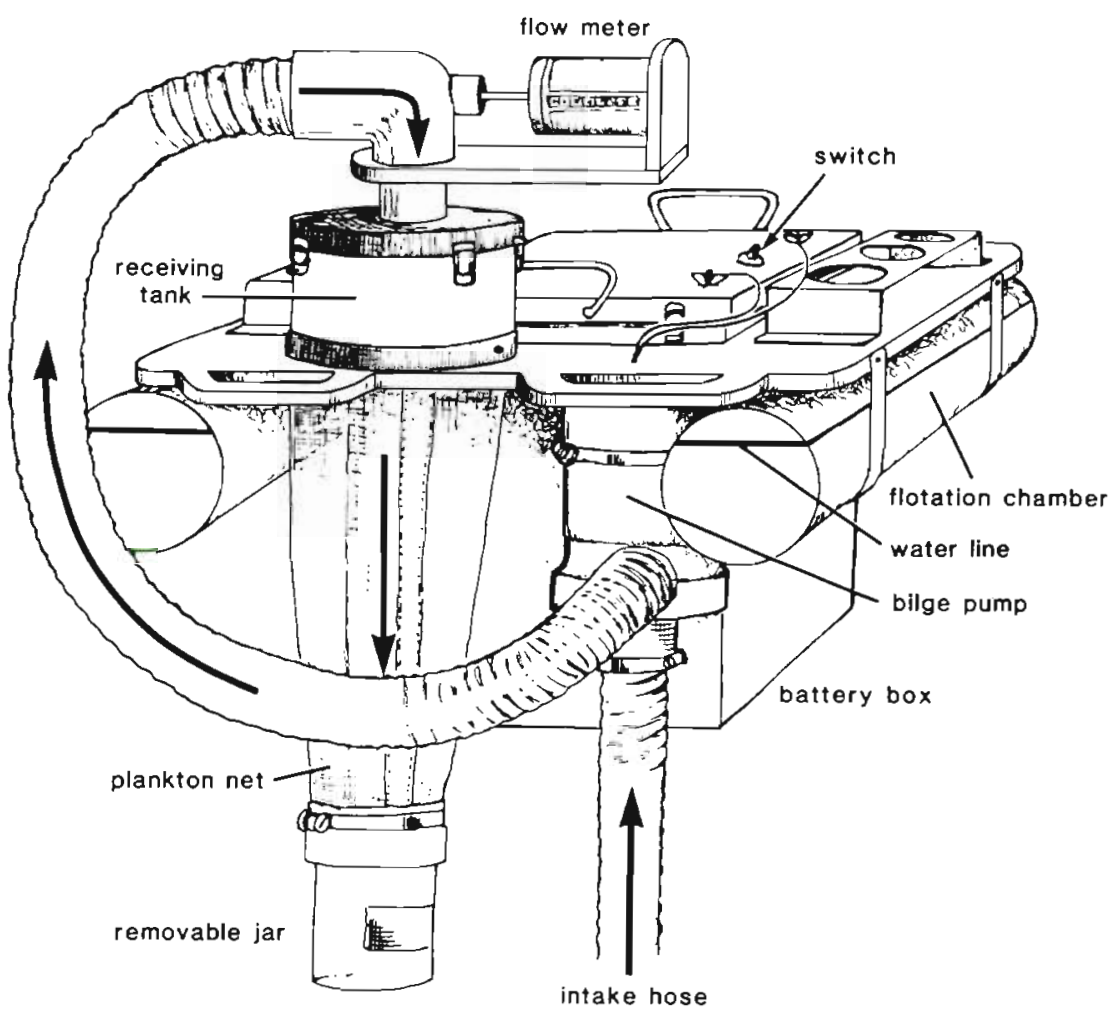

Fig. 1. Diagram of EZY-ZOOP pump system showing positioning of bilge pump, flow meter and receiving tank. Arrows give the direction of water flow time, owing to loss of charge in the battery, changes in the condition of the electrical connections, and the condition of the pump itself. The mean ( $\pm 1 \mathrm{SE}$ ) volume of water sampled in nine 5 min pumping sessions in July and August 1985 was $0.372 \pm 0.020 \mathrm{~m}^{3}$.

Once past the flow meter, water is filtered through a small plankton net mounted below water level (Fig. 1). A stainless steel wire is sewn into the neck of the net to facilitate clamping within the receiving tank (Fig. 1). After the required sampling time, the pump is turned off, the lid of the receiving tank opened and the net removed. The net is then washed down and the sample transferred to a jar which is stored on small racks mounted on the top of the sampler.

The complete sampler is $80 \mathrm{~cm}$ long $\times 51 \mathrm{~cm}$ wide $\times 40 \mathrm{~cm}$ deep and weighs $32 \mathrm{~kg}$. It can be lifted by 1 person, although it is usually helpful to have 2 people lower the unit into the water. Once floating, it is manoeuvred and operated easily by 1 person and performance is not affected by over-washing water.

Performance. We compared the performance of the EZY-ZOOP pump with that of a standard zooplankton net $150 \mathrm{~cm}$ diameter mouth, $105 \mu \mathrm{m}$ mesh, and fitted with General Oceanics flow meter) in both July and August 1985. EZY-ZOOP was fitted with a $105 \mu \mathrm{m}$ mesh net, and all samples were taken on daytime low tides in the mainstream (depth $5 \mathrm{~m}$ ) of Alligator Creek $\left(19^{\circ} 21^{\prime} \mathrm{S}, 146^{\circ} 57^{\prime} \mathrm{E}\right)$, a mangrove-dominated estuary in north Queensland, Australia. Net tows were each of
5 min duration and each EZY-ZOOP sample was from a 5 min pumping session. All samples were taken within the top $2 \mathrm{~m}$ of water. For the purpose of these comparisons EZY-ZOOP was allowed to float next to a stationary boat during sampling runs. On each date all samples were taken within a 45 min period.

Eight taxa (Table 1) made up more than $99 \%$ of the total zooplankton catch in each sample. Net and pump samples yielded faunas with similar taxonomic composition on both sampling dates (Spearman rank correlations on mean abundances from Table 1 ; July, $r_{5}=$ 0.83, $p<0.02$; August, $r_{s}=0.74, p<0.05$ ).

Three groups, copepods, zoea and nauplii made up more than $78 \%$ of the total numbers of zooplankton captured on each sampling date. For these 3 taxa there was no significant difference in the mean densities estimated by net or pump samples (Table 1). The analysis also indicated that the densities of copepods and nauplii were significantly greater in the August samples, but more importantly, as far as the comparison of samplers is concerned, the method $\times$ date interaction term of the ANOVA was not significant. This shows that the samplers acted consistently through time.

Of the remaining 5 taxa shown in Table 1 , chaetognaths, polychaete larvae and larvaceans were captured in significantly greater densities with the plankton net, while gastropod and bivalve larvae were more abundant in the pump samples. Lack of significant method 
Table 1 Mean ( $\pm 1 \mathrm{SE}$ ) densities of zooplankton taxa per $\mathrm{m}^{3}$ for net and pump samples in July and August 1985 based on $\mathrm{n}=3$ for each cell. Numbers in brackets are the mean volumes $\left(\mathrm{m}^{3}\right)$ filtered in standard 5 min samples. For each taxa, means were compared using a 2-way ANOVA with method $(\mathrm{M})$ and date (D) as factors. NS: not significant; ${ }^{\cdot} p<0.05 ;{ }^{\prime} p<0.01$; $\cdots p<0.001$

\begin{tabular}{|c|c|c|c|c|c|c|c|}
\hline \multirow[t]{2}{*}{ Taxa } & \multicolumn{2}{|c|}{4 Jul 1985} & \multicolumn{2}{|c|}{29 Aug 1985} & \multicolumn{3}{|c|}{ Significance of F-ratios } \\
\hline & $\begin{array}{c}\text { Net } \\
(52.13)\end{array}$ & $\begin{array}{l}\text { Pump } \\
(0.35)\end{array}$ & $\begin{array}{c}\text { Net } \\
(42.79)\end{array}$ & $\begin{array}{l}\text { Pump } \\
(0.41)\end{array}$ & M & $\mathrm{D}$ & $M \times D$ \\
\hline Chaetognaths & $30 \pm 8$ & $13 \pm 5$ & $18 \pm 2$ & $13 \pm 2$ & $\cdot$ & NS & NS \\
\hline Polychaete larvae & $70 \pm 4$ & $35 \pm 6$ & $102 \pm 10$ & $44 \pm 8$ & $\cdots$ & $\cdot$ & NS \\
\hline Gastropod larvae & $518 \pm 98$ & $652 \pm 119$ & $165 \pm 48$ & $438 \pm 68$ & $\cdot$ & $\cdot$ & NS \\
\hline Nauplii & $496 \pm 17$ & $460 \pm 24$ & $970 \pm 108$ & $1106 \pm 96$ & NS & $\cdots$ & NS \\
\hline Zoea & $235 \pm 58$ & $168 \pm 25$ & $203 \pm 97$ & $186 \pm 71$ & NS & NS & NS \\
\hline Copepods & $2442 \pm 71$ & $2255 \pm 160$ & $5009 \pm 659$ & $5604 \pm 236$ & NS & $\cdots$ & NS \\
\hline Larvaceans $^{a}$ & $31 \pm 11$ & $6 \pm 3$ & $158 \pm 47$ & $65 \pm 25$ & $\cdot$ & $\cdots$ & NS \\
\hline Bivalve larvae & $21 \pm 9$ & $67 \pm 8$ & $36 \pm 11$ & $455 \pm 254$ & $\cdots$ & $\cdot$ & NS \\
\hline
\end{tabular}

$x$ date interaction term in the ANOVA's for these taxa also indicated the consistency of the samplers with time (Table 1). A major factor which may have led to larger catches of chaetognaths, polychaetes and larvaceans was the much greater volumes of water sampled with the net (Table 1). Given the notoriously patchy nature of zooplankton, it is much more likely that sampling larger volumes of water led to the overall greater mean densities of these rarer zooplankton taxa (Table 1). In addition rapid swimmers such as the chaetognaths probably have greater ability to avoid the pump intake (e.g. Singarajah 1969). Since we did not observe torn pieces of chaetognaths in our pump samples it appears unlikely that lower density estimates resulted from destruction of these organisms during passage through the sampler. However, it is difficult to explain the consistently higher densities of gastropod and bivalve larvae in pump samples (Table 1). Previous studies of lake zooplankton and stream invertebrate drift have also shown that pumps sample greater densities of the smaller taxa present in each habitat (Armitage 1978, Waite \& O'Grady 1980, Williams 1985).

The EZY-ZOOP sampler provided reliable (relative to net samples) estimates of density for major groups of the small zooplankton organisms encountered in a tropical, mangrove-dominated estuary. Up to the present, all mangrove zooplankton studies have been based on samples taken within the mainstreams of mangrove-dominated estuaries (e.g. Chua 1973, Tundisi et al. 1973, Sarkar et al. 1984, Marumo et al. 1985). The sampler described herein will allow samples to be taken in the shallower regions of this important tropical habitat. Preliminary data on the high-tide densities of various zooplankton taxa within a forest of Rhizophora stylosa and in the mainstream of the creek draining this forest (Table 2) revealed that the numbers of zooplankters in forest water were generally much lower, with the exception of zoea which were more abundant amongst prop roots on 1 of the 2 sampling dates.

It is likely that the EZY-ZOOP system could also be used in a variety of other shallow marine habitats. For instance, some of the sampling problems encountered with zooplankton traps used to investigate nocturnal vertical migration of demersal reef zooplankton (see Youngbluth 1982) may be overcome by using a pumping system like the one described, to sample discrete depth zones above reefs. Similarly, the smaller zooplankton of reef areas that are difficult to sample with conventional nets, e.g. reef flats or microhabitats amongst coral heads, may also be studied using light, portable pump samplers. Although the present sampler is not submersible, simple packaging of the pump and battery system, as described for an in situ larval incubation system recently described by Olsen (1985), would allow operation of the system underwater. In the case of submerged work the output from the pump would have to be fed directly into a sampling bottle in a similar fashion to that described in Kennelly \&

Table 2. Mean ( $\pm 1 \mathrm{SE}$ ) daytime densities of zooplankton per $\mathrm{m}^{3}$ within the Rhizophora stylosa forest (pump samples) and in the mainstream (net samples) of the Alligator Creek estuary. All samples taken at high tide and $n=3$ for each cell

\begin{tabular}{|lccrr|}
\hline \multicolumn{1}{|c}{ Taxa } & \multicolumn{2}{c}{4 Jul 1985} & \multicolumn{2}{c|}{29 Aug 1985 } \\
& Forest & Mainstream & Forest & Mainstream \\
\hline Nauplii & $84 \pm 43$ & $499 \pm 24$ & $4 \pm 2$ & $1497 \pm 93$ \\
Zoea & $267 \pm 94$ & $64 \pm 43$ & $7 \pm 3$ & $41 \pm 10$ \\
Copepods & $686 \pm 222$ & $2137 \pm 198$ & $90 \pm 15$ & $5790 \pm 62$ \\
\hline
\end{tabular}


Underwood (1985), to avoid the time-consuming return to the surface required to empty the net after each sample.

\section{LITERATURE CITED}

Alldredge, A. L., King, J. M. (1977). Distribution, abundance and substrate preferences of demersal reef zooplankton at Lizard Island Lagoon, Great Barrier Reef. Mar. Biol. 41: 317-333

Armitage, P. D. (1978). Catches of invertebrate drift by pump and net. Hydrobiologia 60: 229-233

Aron, W. (1958). The use of a large capacity portable pump for plankton sampling with notes on plankton patchiness. J. mar. Res. 16: 158-173

Beers, J. R., Steward, G. L., Strickland, J. D. H. (1967). A pumping system for sampling small plankton. J. Fish. Res. Bd Can. 24: 1811-1818

Chua, T. E. (1973). An ecological study of the Ponggol estuary in Singapore. Hydrobiologia 43: 505-533

Herman, A. W., Mitchell, M. R., Young, S. W. (1984). A continuous pump sampler for profiling copepods and chlorophyll in the upper oceanic layers. Deep Sea Res. 31 : 439-450

Hobson, E. S., Chess, J. R. (1976). Trophic interactions among fishes and zooplankters near shore at Santa Catalina Island, California. Fish. Bull. U.S. 74:567-598

Hobson, E. S., Chess, J. R. (1979). Zooplankters that emerge from the lagoon floor at night at Kune and Midway Atolls, Hawaii. Fish. Bull. U.S. 77: 275-280

Icanberry, J. W., Richardson, R. W (1973). Quantitative sampling of live zooplankton with a filter-pump system Limnol. Oceanogr. 18: 333-335

Kennelly, S. J., Underwood, A. J. (1985). Sampling of small invertebrates on natural hard substrata in a sublittoral kelp forest. J. exp. mar. Biol. Ecol. 89: 55-67

Lenz, J. (1972). A new type of plankton pump on the vacuum principle. Deep Sea Res. 19: 453-459

Marumo, R., Laoprasert, S., Karnjanagesorn, C. (1985). Plankton and near bottom communities of the mangrove regions in Ao Khung Kraben and the Chantaburi River, Thailand In: 'Mangrove estuarine ecology in Thailand'. ThaiJapanese cooperative research project on mangrove productivity and development 1983-1984, Japanese Ministry of Education, Science and Culture, p. 55-74
Miller, C. D., Judkins, D. C. (1981). Design of pumping systems for sampling zooplankton, with descriptions of two high-capacity samplers for coastal studies. Biol Oceanogr. 1: 29-56

Olson, R. R. (1985). In situ culturing of larvae of the crown-ofthorns starfish Acanthaster planci. Mar. Ecol. Prog. Ser 25: $207-210$

Porter, J. W., Porter, K. G. (1977). Quantitative sampling of demersal plankton migrating from different coral reef substrates. Limnol. Oceanogr. 22: 553-556

Sale, P. F., McWilliam, P. S., Anderson, D. T. (1976). Composition of the near-reef zooplankton at Heron Reef, Great Barrier Reef. Mar. Biol. 34: 59-66

Sarkar, S., Baidya, A., Bhunia, A., Choudury, A. (1984). Zooplankton studies in the Hooghly estuary around Sagar Island, Sunderbans, India. In: Soepadmo, E., Rao, A. N., Macintosh, D. J. (ed.) Proceedings of the Asian Symposium on mangrove environment research and management. Unesco, Paris, p. 286-297

Singarajah, K. C. (1969). Escape reactions of zooplankton: the avoidance of a pursuing siphon tube. J. exp. mar. Biol. Ecol. 3: 171-178

Tranter, D. J., Bulleid, N. C., Campbell, R., Higgins, H. W. Rowe, F., Tranter, H. A., Smith, D. F. (1981). Nocturnal movements of phototactic zooplankton in shallow waters. Mar. Biol. 61: 317-326

Tundisi, J., Tundisi, T. M., Kutner, M. B. (1973). Plankton studies in a mangrove environment VIII. Further investigations of primary production, standing-stock of phytoand zooplankton and some environmental factors. Int. Revue. ges. Hydrobiol. 58: 925-940

Waite, S. W., O'Grady, S. M. (1980). Description of a new submersible filter-pump apparatus for sampling plankton. Hydrobiologia 74: 187-191

Williams, C. J. (1985). A comparison of net and pump sampling methods in the study of Chironomid larval drift Hydrobiologia 124: 243-250

Yocum, W. L., Evans, M. S., Hawkins, B. E. (1978). A comparison of pump sampling systems for live zooplankton collection. Hydrobiologia 60: 199-202

Youngbluth, M. J. (1982). Sampling demersal zooplankton: a comparison of field collections using three different emergence traps. J, exp. mar. Biol. Ecol. 61: 111-124

Accepted for printing on May 16, 1986 